University of Nebraska - Lincoln

DigitalCommons@University of Nebraska - Lincoln

\title{
American Indian Civil War treaties: The instruments formed by the Confederate States of America in Indian Territory
}

\author{
Charles D. Bernholz \\ University of Nebraska-Lincoln, cbernholz2@unl.edu \\ Laura Weakly \\ University of Nebraska-Lincoln, Iweakly2@unl.edu \\ Brian Pytlik Zillig \\ University of Nebraska-Lincoln, bzillig1@unl.edu \\ Karin Dalziel \\ University of Nebraska-Lincoln, kdalziel2@unl.edu
}

Follow this and additional works at: https://digitalcommons.unl.edu/libraryscience

Part of the Library and Information Science Commons

Bernholz, Charles D.; Weakly, Laura; Pytlik Zillig, Brian; and Dalziel, Karin, "American Indian Civil War treaties: The instruments formed by the Confederate States of America in Indian Territory" (2011). Faculty Publications, UNL Libraries. 234.

https://digitalcommons.unl.edu/libraryscience/234

This Article is brought to you for free and open access by the Libraries at University of Nebraska-Lincoln at DigitalCommons@University of Nebraska - Lincoln. It has been accepted for inclusion in Faculty Publications, UNL Libraries by an authorized administrator of DigitalCommons@University of Nebraska - Lincoln. 
Published in Library Collections, Acquisitions, \&Technical Services 35 (2011), pp. 29-31; doi: 10.1016/j.lcats.2010.12.006

Copyright (C) 2011 Elsevier Ltd. Used by permission. http://www.elsevier.com/locate/lcats

Published online February 12, 2011.

\title{
American Indian Civil War treaties: The instruments formed by the Confederate States of America in Indian Territory
}

\author{
Charles D. Bernholz, ${ }^{1}$ Laura K. Weakly, ${ }^{2}$ Brian L. Pytlik Zillig, ${ }^{2}$ and Karin Dalziel ${ }^{2}$ \\ 1. Love Memorial Library, University of Nebraska-Lincoln, Lincoln, NE 68588, USA \\ 2. Electronic Text Center, Love Memorial Library, University of Nebraska-Lincoln, Lincoln, NE 68588, USA \\ Corresponding author — C. D. Bernholz, fax 402 472-5181, email cbernholz2@unl.edu
}

\begin{abstract}
The creation of nine treaties between the Confederate States of America (CSA) and the tribes residing in Indian Territory in 1861 formed a significant historical perspective to the understanding of the relationships between governments and indigenous peoples of the United States. This research note describes a Web page - "So Long as Grass Shall Grow and Water Run: The Treaties Formed By the Confederate States of America and the Tribes in Indian Territory, 1861" - that provides access to paired CSA Statutes at Large page images and their text for each of these instruments.
\end{abstract}

Keywords: American Indian treaties, Confederate States of America, Civil War, Indian Territory

\section{Introduction}

Since the reign of Ramesses II, Pharaoh of Egypt, and his alliance with the Hittites in 1259 BC, the universe of diplomacy between sovereigns has been documented through the implementation of treaties. In this ancient instance, aspects of nonaggression, peace, and extradition were negotiated (Menu, 1998, pp. 96-97) and published on a silver tablet in Akkadian, the useful cuneiform language (Marcus, 1978). Models of international relations such as this prevailed and slowly evolved into concepts of international law, beginning with the termination of the Thirty Years' War under the conditions of the Treaty of Osnabrück (Parry, 1969, pp. 198-269). The rules and protocols applied in this transaction of 1648 formed the basis for subsequent global agreements over the next three and a half centuries. Aust noted that if "law derives its strength from acceptance by society that its rules are binding, not from its enforceability, then international law is law. The raison d'être of international law is that relations between states should be governed by common principles and rules" (Aust, 2005, pp. 2-3).

Pushing the bounds of exploration, however, led to a variety of processes to rationalize such behavior. Whenever there was a need for permission, say, to initiate an invasion of Ireland, or to allocate title and a trading monopoly in Africa, or to partition the geography of the New World, papal bulls were employed to expedite such activities and to endow an official air to them (Williams, 1983). Thus, in the New World, the range of new endeavors invoked the creation of its own suite of treaties, conventions, and agreements to formulate a new order.

This was particularly the case for dealings with the indigenous peoples of North America. Indeed, as the result of a series of transactions made prior to American Independence, and then completed during several decades thereafter, 375 treaties acknowledged by the United States Department of State now relay the history of such interactions between the tribes and the newcomers. Charles J. Kappler, in the second volume of his Indian Affairs: Laws and Treaties compiled at the request of Congress (Kappler, 1904), assembled most of these contracts carried out with the tribes. These materials have been digitized by the Oklahoma State University Library Electronic Publishing Center (OSU). The OSU project began modestly, by targeting "all of the pre-removal treaties of the Five Tribes: Cherokee, Chickasaw, Choctaw, Creek, and Seminole. These tribes were chosen because of their significance to the state of Oklahoma," but 
the remaining instruments and Kappler volumes were digitized subsequently (Holcombe, 2000, and Bernholz \& Holcombe, 2005).

Two early American documents from 1798 and 1805, however, were not included in Kappler's second volume of recognized treaty texts, nor were those seven contracts formed by the British government during its tenure. A supplemental Web site now furnishes access to all 375 American Indian treaties (Bernholz, Pylik Zillig, Weakly, \& Bajaber, 2006; http:// earlytreaties.unl.edu/index.html ).

\section{American Civil War treaties created by the Confederate States of America}

Following their removal to Indian Territory in the first few decades of the nineteenth century, the Five Civilized Tribes held almost all of the land that makes up today's Oklahoma (The map on p. 70 of Prucha's Atlas volume [1990] shows this area). At the onset of the Civil War, the CSA sent Albert Pike to negotiate and secure treaties with these tribes. Pike offered a vast array of opportunities in order to attract and seal the allegiance of these groups, including proposals of annuities based on previous negotiations with the federal government, of statehood for the Territory under the government of the CSA, and of representation in the CSA's Congress. At the end of the conflict, the federal government initiated a new series of punitive treaties with the Five Civilized Tribes that simultaneously reduced their land holdings and opened up the Territory to receive other tribes that were displaced under the same forced relocation policies.

The nine instruments created by Pike during July, August, and October of 1861 are nowoffered in digital format at a newWeb site entitled "So Long as Grass Shall Grow and Water Run: The Treaties Formed By the Confederate States of America and the Tribes in Indian Territory, 1861."The site's URL is http://csaindiantreaties.unl.edu. The Statutes at Large of the Provisional Government of the Confederate States of America (Matthews, 1864/1988) now serves as the primary source for these items, and this publication has been digitized by the University of North Carolina as part of theirWeb project Documenting the American South (http://docsouth.unc.edu/index.html). The treaties' texts appear in a segment devoted to a "List of the PublicActs and Resolutions of the Provisional Congress, and of the Proclamations and Treaties Contained in this Volume."This particular contentwas copied fromtheAmerican South site and then rechecked against that found in the paper version of the Statutes. Images of the appropriate pageswere taken fromthis latter resource as well. The resulting Statutes pairs - image plus text - for each of the nine instruments form the presentation for these materials.

\section{Research applications and conclusions}

These digitized texts occupy a single file that furnishes the entire range of 123 pages for the American Indian treaties in the CSA Statutes. Browser text searching of any of the nine documents may therefore be initiated. As an example, many of the tribes in Indian Territory had a tradition of slavery and shared this history with the South. The CSA treaties provided specific articles validating this activity, so the use of the browser search term slavery within the treaty file will yield the seven occurrences contained in these instruments. Similarly, federal annuities were a major interest to these groups and the CSA assured the tribes that this income stream would be maintained under their administration. Searching these documents with the pseudo-term annuit will identify all forty-two relevant instances of annuity and annuities. Required military service was also a provision, and the employment of the term troop will unveil twentyseven examples of troops, but these results include the identification of Texan troops that were to be withdrawn as a condition in the two transactions with the Comanches.

A major reason for offering this suite of CSA treaties was to present the remaining instruments that are missing from a complete collection of all such recognized American Indian transactions (Deloria \& DeMallie, 1999). The fact that the federal government cited these accords in their new post-Civil War dealings with the Indian Territory tribes is an implicit statement of their validity as a full-fledged binding contract. These outcomes may be unfamiliar, but they served as the foundation for a new and different federal policy within Indian Territory after the War. Their importance as historical exemplars endures.

The CSA document group thus supplements the materials available at the American Indian Treaties Portal of the University of Nebraska-Lincoln's Center for Digital Research in the Humanities. This assembly now includes those 
noted early American and British treaties; a biography of Charles J. Kappler, the compiler of Indian Affairs: Laws and Treaties; an analysis of the full lexicon for all 375 recognized treaties; and access to published articles on those treaties cited before a variety of federal and state courts (see http://treatiesportal.unl.edu/).

Finally, the opportunity to provide these nine CSA treaties complements the initiative founded upon OSU's bold development of the Indian Affairs: Laws and Treaties site a decade and a half ago, an endeavor that commenced by focusing on the pre-removal instruments of the Five Civilized Tribes. This group was pivotal in the evolution of Indian Territory into the state of Oklahoma, and it was enmeshed in these dialogues with the CSA during, and with the federal government both before and after, the Civil War. This path - through eight decades of negotiations with one government or another - offers a significant chapter in American history and mirrors how this nation went about setting its course following Independence.

\section{References}

Aust, A. (2005). Handbook of International Law. New York: Cambridge University Press.

Bernholz, C. D., \& Holcombe, S. L. (2005). The Charles J. Kappler Indian Affairs: Laws and Treaties Internet site at the Oklahoma State University. Library Collections, Acquisitions, and Technical Services, 29, 82-89.

Bernholz, C. D., Pytlik Zillig, B. L., Weakly, L. K., \& Bajaber, Z. A. (2006). The last few American Indian treaties-An extension of the Charles J. Kappler Indian Affairs: Laws and Treaties Internet site at the Oklahoma State University. Library Collections, Acquisitions, and Technical Services, 30, 47-54.

Deloria, V., \& DeMallie, R. J. (1999). Documents of American Indian Diplomacy:Treaties, Agreements, and Conventions, 1775 -1979, vol. 1. Norman, OK: University of Oklahoma Press.

Holcombe, S. L. (2000). Bringing Indian Affairs: Laws and Treaties to the World Wide Web. Available at http://www.fdlp.gov/ home/repository/cat view/177-outreach/97-events/101-depository-library-council-dlc-meetings/124-2000-meetingproceedings / 125 -fall-dlc-meeting-arlington-va

Kappler, C. J. (1904). Indian affairs. Laws and treaties, vol. 2. Treaties. Senate. 58th Congress, 2nd session. Senate Document No. 319, part 2 (Serial Set 4624). Washington, DC: Government Printing Office.

Marcus, D. (1978). A Manual of Akkadian. Lanham, MD: University Press of America.

Matthews, J. M. (1864/1988). The Statutes at Large of the Provisional Government of the Confederate States of America. Buffalo, NY: W.S. Hein.

Menu, B. (1998). Ramesses II, Greatest of the Pharaohs. New York: Harry N. Abrams.

Parry, C. (1969). The Consolidated Treaty Series, vol. 1. Dobbs Ferry, NY: Oceana.

Prucha, F. P. (1990). Atlas of American Indian Affairs. Lincoln, NE: University of Nebraska Press.

Williams, R. A. (1983). The medieval and renaissance origins of the American Indian in western legal thought. Southern California Law Review, 57, 1-99. 